\begin{tabular}{|l|l|l|l|l|}
\hline $\begin{array}{l}\text { Cuadernos de Investigación Geográfica } \\
\text { Geographical Research Letters }\end{array}$ & 2020 & N$^{\circ} 46(1)$ & pp. 127-139 & eISSN 1697-9540 \\
\hline
\end{tabular}

DOI: http://doi.org/10.18172/cig.4331

(C) Universidad de La Rioja

\title{
GLACIER AND CLIMATE EVOLUTION IN THE PARIACACÁ MOUNTAINS, PERU
}

\author{
J. I. LÓPEZ-MORENO ${ }^{1 *}$, F. NAVARRO ${ }^{1}$, E. IZAGIRRE ${ }^{2,3}$, \\ E. ALONSO ${ }^{1}$, I. RICO ${ }^{4}$, J. ZABALZA ${ }^{1}$, J. REVUELTO ${ }^{1}$
}

${ }^{1}$ Instituto Pirenaico de Ecología, IPE-CSIC, Avda Montañana 1005, 50059 Zaragoza, Spain.

${ }^{2}$ Basque Centre for Climate Change, BC3, Sarriena s/n, 48940 Leioa, Spain.

${ }^{3}$ Hidro-Environmental Processes Group, University of the Basque Country UPV/EHU, Sarriena s/n, 48940 Leioa, Spain.

${ }^{4}$ Dept. of Geography, Prehistory and Archaeology, University of the Basque Country UPV/EHU, Tomás y Valiente s/n, 01006 Vitoria-Gasteiz, Spain.

\begin{abstract}
Glaciers in Peru play a major role in water availability and they also have direct implications on natural hazards such as glacial lake outburst floods (GLOFs) and/or ice avalanches, which have caused a high number of fatalities and damage to infrastructure in the last decades. Despite a noticeable effort to quantify and understand the shrinking and thawing of glaciers in Peru, there are still regions where detailed assessment is still missing.
\end{abstract}

In this work, a set of remote sensing images were used to map, for the first time, the evolution of the glaciated area (from 1970 to 2018) in the Pariacaca Mountains $\left(11^{\circ} 5^{\prime} \mathrm{S}, 76^{\circ} 0^{\prime} \mathrm{W}\right)$ in the Cordillera Central of Peru. The results evidenced a marked decrease of the glaciated surface, with $55.3 \%$ shrinkage since 1970 and 40\% since 1987. Faster glacier retreat occurred between 1985 and the end of the 1990s, and this period was followed by a significant slowdown in shrinking rates. The differential loss of ice, depending on elevation and exposure to incoming radiation, has led to changes in spatial distribution of the glaciers. Currently, they have almost completely thawed below $5000 \mathrm{~m}$ a.s.l. They are mostly located in south-to west-facing aspects. Ice melting in the last decades has even affected the summit areas. Finally, the development of ablation hollows has been identified as an important driver of glacier thaw. These features are formed mainly in gentle slopes and highly irradiated zones between 5000 and $5400 \mathrm{~m}$ a.s.l.

\section{Evolución glaciar y climática en las montañas de Pariacacá, Perú}

RESUMEN. Los glaciares en Perú juegan un papel fundamental en la disponibilidad de agua y también poseen claras implicaciones en la ocurrencia de riesgos 
naturales como desbordamientos de lagos (GLOFs) y/o avalanchas de hielo que han causado un gran número de víctimas y daños a infraestructuras en las últimas décadas. A pesar del gran esfuerzo que se ha realizado para cuantificar y comprender el retroceso de los glaciares en Perú, aún existen regiones donde se carece de un estudio detallado.

En este trabajo, se utilizan imágenes de satélite para cartografiar por primera vez la evolución de la superficie cubierta por glaciares (durante el periodo

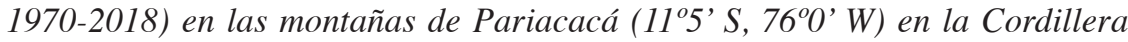
Central de Perú. Los resultados evidencian un marcado retroceso glaciar, afectando al $55.3 \%$ desde 1970 y al 40\% desde 1987. El periodo de mayor retroceso sucedió entre 1985 y el final de los años 90, periodo seguido por una ralentización en los ratios de fusión. Las diferencias en desaparición de hielo según altura y orientación han llevado a claros cambios en la distribución espacial de los glaciares. Actualmente, se encuentran mayoritariamente en caras sur y este. La desaparición de hielo ha llegado a afectar en los últimos años a los sectores cimeros. Finalmente, también se ha analizado la evolución de grandes depresiones de fusión sobre los glaciares que han sido identificados como un elemento significativo para acelerar la degradación de los glaciares. Estas formas aparecen fundamentalmente en zonas con elevada radiación, entre los 5000 y 5400 m s.n.m.

Key words: Glaciers, Remote sensing, glaciated area, ablation hollows, Pariacacá Mountains, Peru.

Palabras clave: glaciares, teledetección, superficie glaciada, depresiones de fusión, Cordillera Pariacacá, Perú.

Received: 1 August 2019

Accepted: 14 November 2019

*Corresponding author: Juan Ignacio López-Moreno, Instituto Pirenaico de Ecología, Consejo Superior de Investigaciones Científicas (IPE-CSIC), Avda. Montañana 1005, 50059 Zaragoza, Spain. E-mail address: nlopez@ipe.csic.es

\section{Introduction}

Peru hosts the largest area occupied by tropical glaciers in the world. They play a significant role in the supply of water, not only for local communities living in the Andes, but also for large irrigated and urban areas located in the lowlands, including the megacity of Lima and big cities such as Cuzco, Arequipa and Huancayo among others (Vuille et al., 2003). Since the end of the Little Ice Age (LIA), Peruvian glaciers have been thawing, and this trend accelerated after 1970 (Juen et al., 2007). Thus, more than $40 \%$ of the glaciated area has vanished, from the early 1980 s to the present time (Schauwecker et al., 2014; Emmer, 2017). Thawing has particularly affected areas below $5000 \mathrm{~m}$ a.s.l. (Silverio and Jaquet, 2017), where the lost glacier surface exceeded 
80\% (Veettil al., 2017). Glacier changes have already manifested, with shifting river regimes (Mark et al., 2017), the apparition of new lakes (Emmer et al., 2018), changes in erosion processes impacting water quality and numerous catastrophic events, mainly related to glacial lake outburst floods (GLOFs) (Haeberli et al., 2016; López-Moreno et al., 2017).

Recent deglaciation has affected all mountain ranges in Peru, without exception, but the shrinkage rate differs remarkably between analysed areas. For example, (Veettil and de Souza, 2017) reported a loss of $52.2 \%$ and $44 \%$ of surface covered by ice during the periods 1975-2015 and 1985-2015 respectively for the Cordillera Vilcanota. Veettil et al. (2018) reported a decrease of 50\%, 56\%, 30\% and 56.7\% for Huagaruncho, Huaytapallana, Vilcamba and Urumba, respectively, for the period 1985-2015. LópezMoreno et al. (2014) also reported a loss of $56 \%$ of ice cover of the Huaytapallana Mountains for the period 1987-2013. Kochtitzky et al. (2018) reported a reduction of $24 \%$ in the Coropuna region for the period 1984-2014. Silverio and Jaquet (2017) reported a $27.3 \%$ of ice loss in Cordillera Blanca between 1985 and 2016; while other smaller ranges have lost more than $70 \%$ of ice since 1970, as is the case for La Viuda, La Raya, Huanzo and Chila ranges (ANA, 2014). These differences suggest that climate variables may exhibit a different evolution in the different ranges, but it is also possible that glaciers in different mountains respond differently to changing climate as a consequence of their hypsometry and topographic context (López-Moreno et al., 2006; Veettil et al., 2018). Despite the increasing number of studies on glacier evolution in Peru (Rabatel et al., 2013; Vuille et al., 2018), there are still sectors with a noticeable surface covered by glaciers that have been only marginally studied. This is the case of the Pariacacá Mountains in the Cordillera Central, where detailed reconstruction of the recent evolution of the ice-covered surface is still lacking.

This study shows the evolution of glaciers in the Pariacacá mountain range from 1970 to 2018, based on remote sensing imagery. The interannual evolution of the glaciers was contextualized with the topographic characteristics of the recently deglaciated area and also with the climate evolution observed during the study period. Additionally, the spatial distribution of ablation hollows on the glaciated surfaces was quantified and analysed. Ablation hollows are common features in many glaciers of the world, but they are particularly abundant and well represented in the Pariacacá Mountains. They clearly influence the acceleration of glacier thaw, but their presence is still poorly understood.

\section{Study area}

The Pariacacá Mountains (Fig. 1) are part of the Peruvian Central Cordillera located between Junín (eastward) and Lima (westward) Departments of Peru $\left(11^{\circ} 5\right.$ $\mathrm{S}, 76^{\circ} 00^{\prime} \mathrm{W}$ ). With approximately $30 \mathrm{~km}$ length and an average width of $15 \mathrm{~km}$, the Pariacacá mountain range extends north to south from a plateau at $4000 \mathrm{~m}$ a.s.l. The origin of these granitic mountains is tectonic, with no presence of vulcanos in this area. The highest elevation is found at Pariacacá Sur peak (5750 m a.s.1.), and more than 30 peaks exceed $5000 \mathrm{~m}$. The mountains drain to the Pacific through Cañete, Mala and 
Rimac rivers, the latter supplying water to Callao and Lima cities. Population density is very low, the main settlement, located south of the range, being the town of Tanta (4300 m a.s.l.; 600 inhabitants). There are many lakes in the region, some of them of large dimensions that are currently used for an incipient fish-farming industry. In addition, the Yuracmayo dam was recently built for hydropower production. The main economic activity in the region is cattle rising, whilst agriculture remains a secondary and marginal sector.

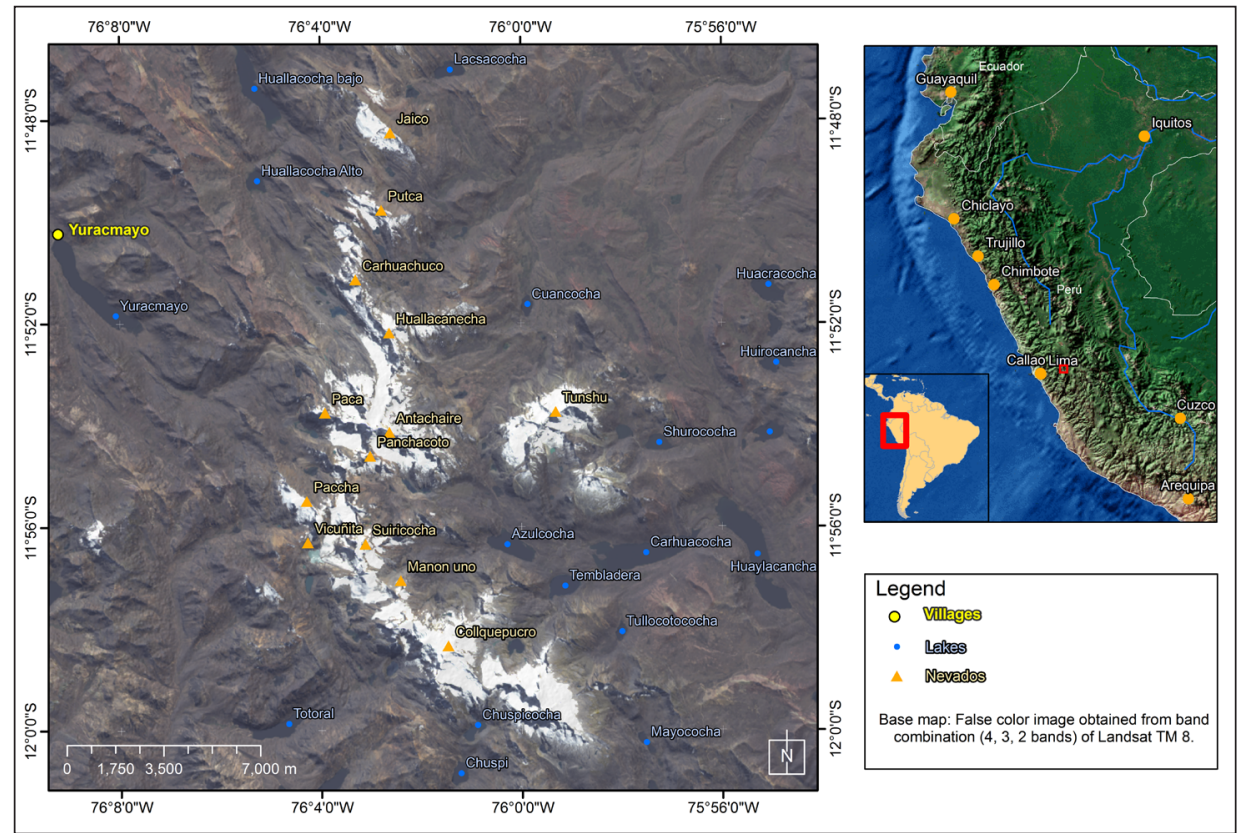

Figure 1. Study area.

\section{Data and methods}

The declassified US spy satellite Corona, KH-4 missions, collected a set of stereo images covering the Pariacacá mountain range on 7 June 1970 (Ruffner, 1995). The images provide historical perspective not available elsewhere, which has been used to obtain a close estimation of glacier extent in 1970. The three Corona strips were obtained from the US Geological Survey (USGS) EarthExplorer visor, with a reported nominal ground resolution of $7.62 \mathrm{~m}$. The resulting orthoimages were georeferenced, identifying non-glacierised tie-points (moraines, lake spillways, river crossings, etc.), which were manually extracted from the panchromatic band of the 2018 Landsat OLI image (spatial resolution of $15 \mathrm{~m}$ ) and 2018 PlanetScope imagery (spatial resolution of $3 \mathrm{~m}$ ) in QGis (v 3.4). Once properly registered, the orthoimages were interpreted visually, and the icecovered area was delineated manually. 
25 scenes of Landsat 5 (TM) and 8 (OLI) imagery were selected for the period 1987-2018 from the dataset available for the end of the dry period (July to September). Due to persistent cloudiness there were no images available for the years 1992 and 2012 (Table 1). The images were downloaded from the USGS website and were subjected to radiometric, geometric and atmospheric correction (López-Moreno et al., 2014).

Table 1. Remote sensing images used in this study and their acquisition date.

\begin{tabular}{|c|c|c|c|}
\hline Corona-KH4 & Landsat 5-TM & Landsat 8-OLI & PlanetScope \\
\hline \multirow[t]{19}{*}{ 1970-06-07 } & 1987-07-27 & 2014-07-- 05 & 2018-05-30 \\
\hline & 1988-07-29 & 2015-07-24 & \\
\hline & 1990-07-19 & 2016-07-26 & \\
\hline & 1991-07-06 & 2017-07-29 & \\
\hline & $1993-06-25$ & 2018-06-31 & \\
\hline & 1994-07-14 & & \\
\hline & $199507-17$ & & \\
\hline & 1996-07-03 & & \\
\hline & 1997-06-20 & & \\
\hline & 1999-07-12 & & \\
\hline & 2000-07-30 & & \\
\hline & 2001-08-02 & & \\
\hline & 2003-07-07 & & \\
\hline & 2004-07-09 & & \\
\hline & 2005-07-12 & & \\
\hline & 2007-07-02 & & \\
\hline & 2008-07-04 & & \\
\hline & 2009-06-05 & & \\
\hline & 2011-07-29 & & \\
\hline
\end{tabular}

Pixels covered by ice were identified, using the band-ratio between satelliteobserved visible red (TM3 and OLI4 respectively) and shortwave infrared (TM5 and OLI6) digital numbers (Rakesh and Bolch, 2009), with a suitable threshold of 2.4 to classify ice cover. This threshold was selected for its maximum accuracy in the validation process ( $99 \%$ of the points were correctly discriminated as ice free/covered) performed with the PlanetScope imagery of 2018 (following the procedure presented by López-Moreno et al., 2014). Despite avoiding the presence of fresh snow when selecting images, this was present for several years. In order to minimize the impact 
of snow on the assessment of ice cover evolution we identified a pixel always free of ice, with the previous and the next year also ice free at the same pixel. Finally, in order to improve glacier delineation in 2018, we analysed five Level 3B scenes collected by the PlanetScope Dove satellite constellation on 30 May 2018, with a resampled ground resolution of $3 \mathrm{~m}$ (Planet Team 2017).

Given the absence of reliable long-term climatic data in the whole region, Reanalysis Data of temperature, precipitation, relative humidity, solar radiation and wind speed were used to consider temporal variability of the mentioned variables during the period of study. ERA 5 data (https://www.ecmwf.int/en/forecasts/datasets/reanalysis-datasets/ era5) at a horizontal resolution of 31 kilometres was used. Despite caution being required when using this data in regions with little or no observations, high resolution reanalysis data has been proven to properly reproduce observed trends, even in mountainous areas (Cornes and Jones, 2013). The reanalysis series from 1980 to 2018 and the ERA 5 data were aggregated annually for both the dry (May to September) and the wet (October to April) seasons. The existence of significant trends was tested using the non-parametric Mann-Kendal test (Kendall, 1975).

In order to analyse the topographic context of the location of the glaciers and the ablation hollows, Digital Elevation Models (DEMs) were used, constructed from ASTER Global Digital Elevation Map (GDEM) data (1 arcsec data, $30 \mathrm{~m}$ resolution) from the NASA EarthData depository (https://gdex.cr.usgs.gov/gdex/) and Radiometric Terrain-Corrected (RTC) ALOS PALSAR Global Radar Imagery (12.5 m resolution) provided by the VERTEX depository (https://vertex.daac.asf.alaska.edu/). Calculated from these DEMs were slope angle, aspect and potential incoming radiation under clear sky conditions using the "Solar Analyst" tool in ArcGIS.

\section{Results}

\subsection{Evolution of surface covered by ice and its topographic context}

According to the analysis performed with the Corona imagery, $68.2 \mathrm{~km}^{2}$ were covered by ice in 1970, and this dropped to $53 \mathrm{~km}^{2}$ in 1987 (Fig. 1). This yields a total loss of $22 \%$ of the glaciated area $\left(0.84 \mathrm{~km}^{2} \mathrm{yr}^{-1}, 1.2 \% \mathrm{yr}^{-1}\right)$ for the $1970-1987$ period. During the period 1988 to 2018 , the glaciated surface shrank to $30.5 \mathrm{~km}^{2}$, which means a loss of $40 \%$ of the ice in the range in this 30 -year period, and $55.3 \%$ since 1970 . Figure 2 shows that the loss of ice is far from regular from one year to other, with specific years when losses are in the range of 2-3 km² (i.e., 1989, 1997 and 2005), while in other years glaciers in the area have shown no significant changes. The period 1988-1997 recorded the highest rate of ice loss $\left(1.62 \mathrm{~km}^{2} \mathrm{a}^{-1}\right.$, or a $\left.3 \% \mathrm{a}^{-1}\right)$, with deceleration after $1998\left(0.5 \mathrm{~km}^{2} \mathrm{a}^{-1}\right.$, or a $\left.1.2 \% \mathrm{a}^{-1}\right)$.

The loss of ice from one year to the other affects differently the different elevation bands and the areas with different exposition to solar radiation, as shown in Figure 3.

The loss of ice from 1970 to 1987 was exacerbated on high radiation slopes located below $5200 \mathrm{~m}$ a.s.1. In fact, during the first decade, more than $25 \%$ of ice losses occurred 


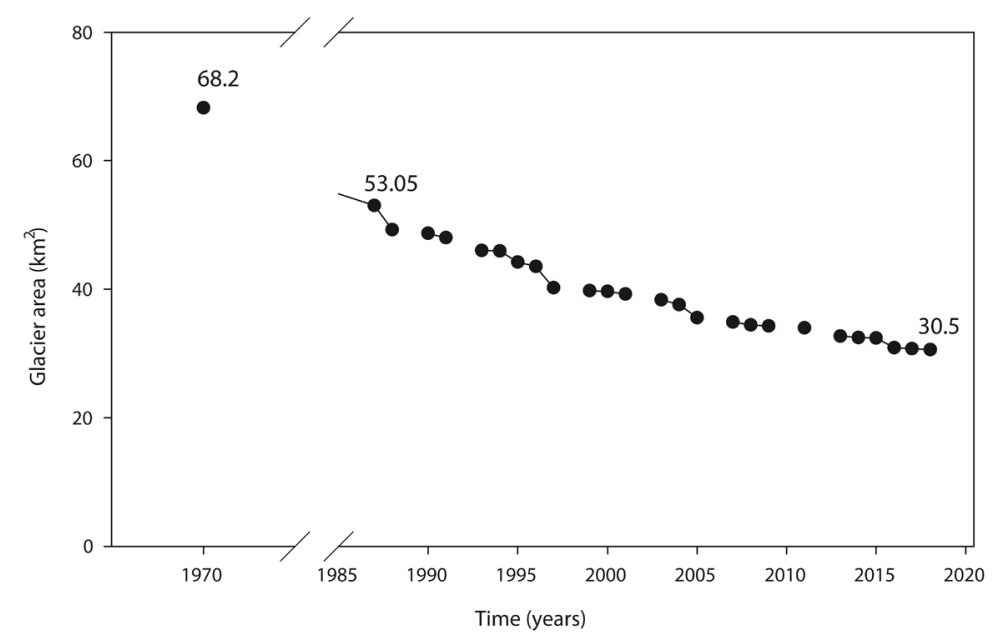

Figure 2. Surface of the Pariacacá Mountains covered by ice in 1970 and its temporal evolution from 1970 to 2018.

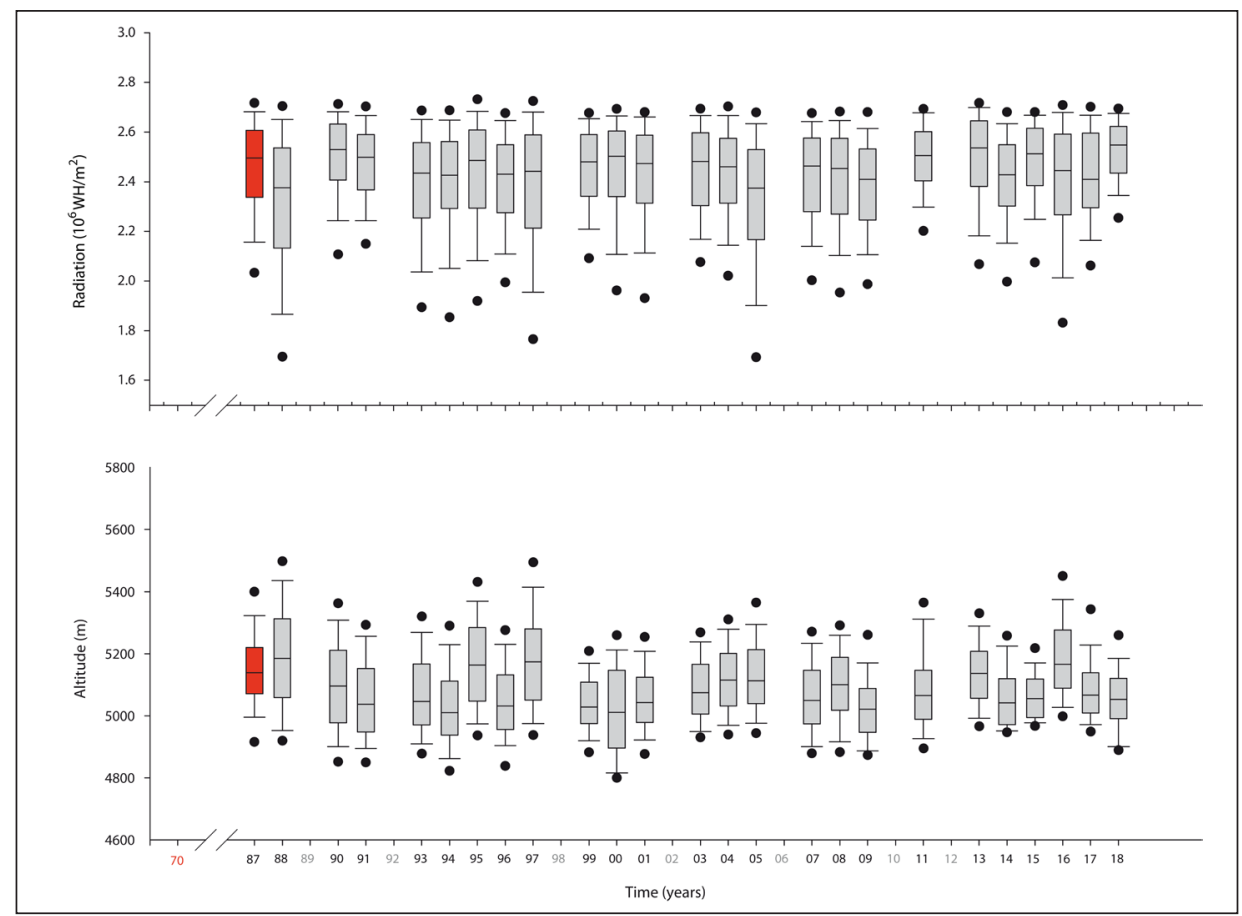

Figure 3. Frequency distribution of elevation and potential incoming radiation (under clear sky) on the glaciated areas that experienced shrinkage during the period 1988-2018. Years where ice cover could not be estimated have been aggregated to the following year. Line indicates the median, boxes the 25 th and 75 th percentiles, bars the 10th and 90th percentiles, and dots the 5th and 95 th percentiles. 
below 5000 m a.s.1., while this percentage was clearly reduced during the 21 st century due to the lack of ice cover at these elevations. The highest quintile of elevation is also subjected to large interannual variability. Hence, some years there is a significant ice loss above 5200 m a.s.1. - with ice losses affecting even the summits $(1988,1995,1997$ and 2016) while other years, the vast majority of ice losses occur only below $5200 \mathrm{~m}$ a.s.l. (i.e., 1999, 2014 and 2015). Similar variability is observed for potential incoming radiation (under clear sky conditions), with years where ice loss occurs in a very wide array of exposures to solar radiation (i.e., 1988, 1997, 2005 and 2016), while in other years ice losses are restricted to slopes that receive the most intense solar radiation (i.e., 1990, 1991, 1999, 2011 and 2018).

The existing contrasts in ice loss, depending on elevation and solar radiation, explain the changes that occurred in preferential aspect and altitude, where ice cover is distributed in the Pariacacá Mountains. Figure 4 shows such differences for the years 1970, 1987, and 2018. In 1970, ice cover was more evenly distributed in different aspects, compared to 1987 and 2017. In the most recent period (1987 to 2018) more than $50 \%$ of the ice in Pariacacá was found in the south and west aspects. In 1970, ice found in the south and west aspects made up $43 \%$ of the total area. Generalised loss of ice below 5000 m a.s.1. (shown in Fig. 3) is obvious, and a relative increase in concentration of the ice covered area for elevation above $5200 \mathrm{~m}$ a.s.l. is observed. Even when distribution of ice is similar, when comparing 1987 and 2018, notable differences exist, with a tendency to decreasing (increasing) concentration of the ice covered area of north and eastern (south and western) aspects, and a complete disappearance of ice at low elevations.

\subsection{Ablation hollows and their spatial distribution}

Ablation hollows are a significant feature of glaciers in the Pariacacá Mountains, as there is very high density in this region. Figure 5 shows two examples where their significant dimensions can be noted - more than 50 meters in diameter and a marked vertical development that, in several cases, reaches the bedrock. Ablation hollows may appear in the middle of glacier tongues or next to the snout. When the latter occurs, it

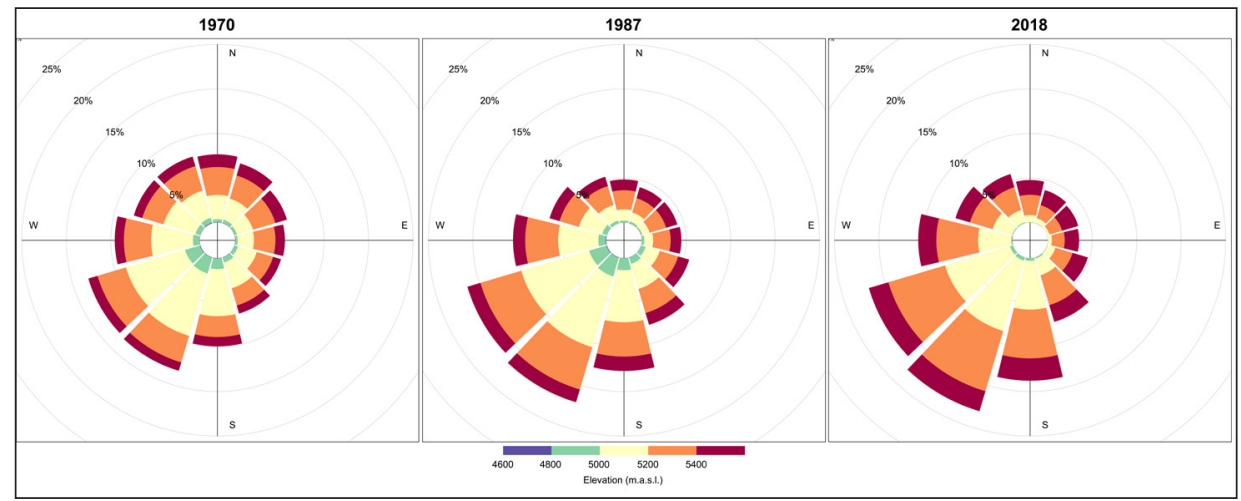

Figure 4. Distribution of area covered by ice at different aspects and elevation in 1970, 1987 and 2018. 
triggers accelerated thawing. In the image from 2018, 78 ablation hollows were counted, distributed throughout the majority of glaciers in the range (Fig. 5). However, they are particularly concentrated (about $40 \%$ of the total number of glaciers) at medium elevations and in the southwest (SW) aspect. Despite the fact that they are preferentially

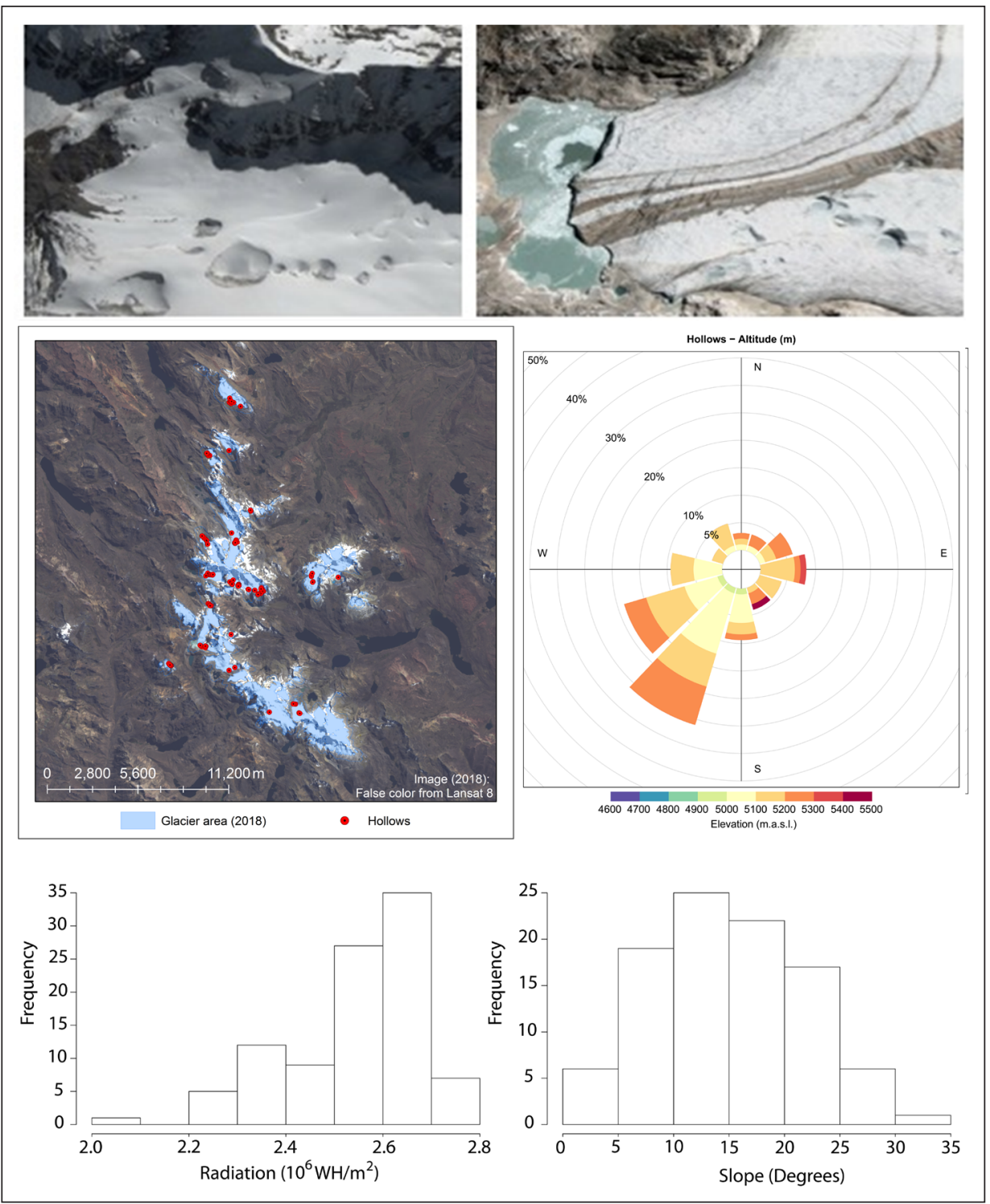

Figure 5. Upper panels: two examples of ablation hollows in glaciers of the Pariacacá Mountains. Middle panels: spatial distribution of ablation hollows (left) and distribution with regard to aspect, elevation. Lower panels: histograms informing about the distribution of ablation hollows depending on potential incoming radiation (left) and slope (right). 
located in the SW aspect, the histogram of incoming solar radiation shows that they mostly develop in areas with high solar radiation levels. Moreover, $80 \%$ of the hollows are located in gentle slopes between 5 and $25^{\circ}$.

\subsection{Recent climatic evolution}

Figure 6 shows the temporal evolution simulated by ERA 5 reanalysis of the main climatic variables that control the energy balance of glaciers during the period 1980-2017. For this specific period, temperature did not show a significant trend during the dry (MaySeptember) or the wet (October to April) seasons, whilst precipitation showed a decrease that is only statistically significant $(\mathrm{p}<0.05)$ during the wet season. Relative humidity did not exhibit changes during the wet season but decreased during the dry months.

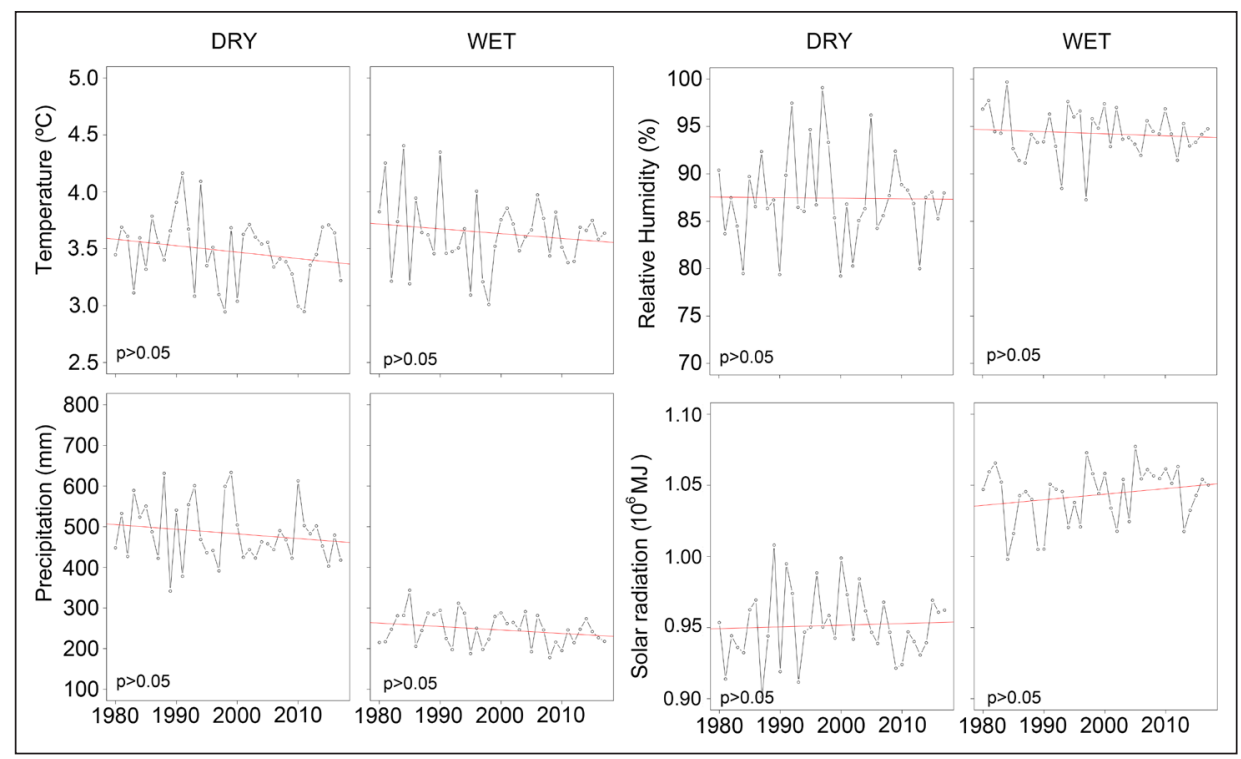

Figure 6. Annual evolution (1980-2017) of temperature, precipitation, relative humidity and incoming solar radiation for the wet and dry season from ERA-5 Reanalysis data.

\section{Discussion and conclusions}

Analysis of remote sensing images in the Pariacacá Mountains revealed that the area covered by ice has shrunk $55.3 \%$ since 1970 and $40 \%$ since 1987 . These values exceed the rates of ice loss estimated in $40 \%$ for the whole Peruvian mountains since 1970 (ANA, 2014) but match with estimated glacier shrinkage for other mountain sectors where elevations do not exceed $6000 \mathrm{~m}$ a.s.l. (Veettil et al., 2018; Burns and Nolin 2014). It is interesting to note that shrinking of Pariacacá glaciers is far from the $56 \%$ reported for the Huaytapallana range (1987-2013), despite being at the same latitude and less than 100 kilometres apart. 
As observed in other mountains of Peru, there was a clear slowdown in the rates of ice shrinking after the late 1990's (Drenkhan et al., 2018). This change corresponds to a lack of temperature trends in the tropical Andes since the analysed series began in 1980 (Vuille et al., 2018; Schauwecker et al., 2017). This behavior of temperatures, corroborated in the Pariacacá region with ERA-5 reanalysis data, has been associated with the cool phase of the Pacific Decadal Oscillation (PDO) since the early 2000s (Vuille et al., 2018). Thus, this situation could potentially be reversed and could lead to accelerated glacier melt (Vuille et al., 2015) if a new cycle of PDO - and the associated rise in temperatures - occurs.

Schauwecker et al. (2017) argued that glacier retreat post-2000 is a consequence of glaciers still reacting to strong warming that occurred before 1980, leading to many low-lying glaciers with a situation of clear imbalance. The increase of incoming solar radiation could be an additional explanation for sustained glacier shrinkage under recent stationary temperature conditions.

The spatial patterns of ice cover retreat have varied over time. During the period 1970 to 1987 , glacier retreat mainly affected slopes with high radiation rates, located below 5200 meters. In the period 1987-2018, an extensive disappearance of the ice below 5000 meters occurred, with a subsequent concentration of surviving glaciers in the south and west aspects. Within the 1987-2018 period, a number of years showed ice thawing affecting both low irradiated slopes and the highest elevations, ultimately leading to the disappearance of ice from many summits of the mountain range. The current distribution of the Pariacacá glaciers (see Figure 4) very closely resembles the one depicted by (Veettil et al., 2017, see Figure 2 of this article) for the Cordillera Vilcanota.

For the first time, the presence of ablation hollows at the ice surface has been quantified and its spatial distribution described. The presence of a total of 75 hollows has been confirmed, mainly concentrated in areas with gentle slope and high incoming solar radiation at mid elevations $(5200-5400 \mathrm{~m})$. Solar radiation seems to be the primary driver of their formation, creating concave surfaces that subsequently act as traps for solar radiation. Nonetheless, detailed analyses about the formation process and evolution, as well as their implication on glacier thawing, requires further research.

Climate scenarios available for the region for the next decades (López-Moreno et al., 2014) suggest that ice loss will continue and even accelerate in the next years, leading to glaciers becoming a marginal component of the high mountain landscape and environment. As pointed out by many authors for other mountain areas of Peru (Vuille et $a l ., 2018$ ), the deglaciation process will impact water quantity and quality in the region, affecting even Lima city. It is also likely to increase the spatio-temporal occurrence of natural hazards associated with lake level rise, slope instabilities and flash floods (Carey 2005; Haeberli et al., 2016).

\section{Acknowledgements}

This research has been taken under the project HIDROIBERNIEVE (CGL201782216-R) funded by the Ministry of Science, Innovation and Universities. 


\section{References}

Autoridad Nacional del Agua 2014. Inventario nacional de glaciares y lagunas. 39 pp. https:// www.ana.gob.pe/sites/default/files/publication/files/inventario_de_glaciares_y_lagunas.pdf.

Burns, P., Nolin, A. 2014. Using Atmospherically-corrected Landsat imagery to measure glacier area change in the Cordillera Blanca, Peru from 1987 to 2010. Remote Sensing of Environment 140, 165-178. https://doi.org/10.1016/j.rse.2013.08.026.

Carey, M., Mark, B. 2005. Living and dying with glaciers: People's historical vulnerability to avalanches and outburst floods in Peru. Global and Planetary Change 47, 122-134. https:// doi.org/10.1016/j.gloplacha.2004.10.007.

Cornes, R., Jones, P. 2013. How well does the ERA-Interim reanalysis replicate trends in extremes of surface temperature across Europe? Journal of Geophysical Research (Atmospheres) 118 , 10262. https://doi.org/10.1002/jgrd.50799.

Drenkhan, F., Guardamino, L., Huggel, C., Frey, H. 2018. Current and future glacier and lake assessment in the deglaciating Vilcanota-Urubamba basin, Peruvian Andes. Global and Planetary Change 169, 105-118. https://doi.org/10.1016/j.gloplacha.2018.07.005.

Emmer, A. 2017. Geomorphologically effective floods from moraine-dammed lakes in the Cordillera Blanca, Peru. Quaternary Science Reviews 177, 220-234.https://doi.org/10.1016/j. quascirev.2017.10.028.

Emmer, A., Vilímek, V., Zapata, M.L. 2018. Hazard mitigation of glacial lake outburst floods in the Cordillera Blanca (Peru): The effectiveness of remedial works. Journal of Flood Risk Management 11 (1), S489-S501. https://doi.org/10.1111/jfr3.12241.

Haeberli, W., Buetler, M., Huggel, C., Friedli, T.L., Schaub, Y., Schleiss, A.J. 2016. New lakes in deglaciating high-mountain regions - Opportunities and risks. Climatic Change 139 (2), 201214. https://doi.org/10.1007/s10584-016-1771-5.

Juen I., Kaser, J.I., Georges, C. 2007. Modelling observed and future runoff from a glacierized tropical catchment (Cordillera Blanca, Perú). Global and Planetary Change 59, 37-48. https://doi.org/10.1016/j.gloplacha.2006.11.038.

Kendall, S. B. 1975. Enhancement of conditioned reinforcement by uncertainty. Journal of the Experimental Analysis of Behavior 24, 311-314. https://doi.org/10.1901/jeab.1975.24-311.

Kochtitzky, W.H., Edwards, B.R. Enderlin, E.M., Marino, J., Marinque, N. 2018. Improved estimates of glacier change rates at Nevado Coropuna Ice Cap, Peru. Journal of Glaciology 64 (244), 175-184. https://doi.org/10.1017/jog.2018.2.

López-Moreno, J. I., Nogués-Bravo, D., Chueca-Cía, J., Julián-Andrés, J. 2006. Change of topographic control on the extent of cirque glaciers since the Little Ice Age. Geophysical Research Letters 33, L24505. https://doi.org/10.1029/2006GL028204.

López-Moreno, J.I., S. Fontaneda, J. Bazo, J. Revuelto, C. Azorin-Molina, B. Valero-Garcés, E. Morán-Tejeda, S.M. Vicente-Serrano, R. Zubieta, and J. Alejo-Cochachín. 2014. Recent glacier retreat and climate trends in Cordillera Huaytapallana, Peru. Global and Planetary Change 112,1-11. https://doi.org/10.1016/j.gloplacha.2013.10.010.

López-Moreno, J.I., Valero-Garcés, B., Mark, B., Condom, T., Revuelto, J., Azorín-Molina, C., Bazo, J., Frugone, M., Vicente-Serrano, S.M., Alejo-Cochachin, J. 2017. Hydrological and depositional processes associated with recent glacier recession in Yanamarey catchment, Cordillera Blanca (Peru). Science of the Total Environment 579 (1), 272-282. https://doi. org/10.1016/j.scitotenv.2016.11.107.

Mark, B.G., French, A., Baraer, M., Carey, M., Bury, J., Young, K,R., Polk, M.H. 2017. Glacier loss and hydro-social risks in the Peruvian Andes. Global and Planetary Change 159, 61-76. https://doi.org/10.1016/j.gloplacha.2017.10.003. 
Rabatel, A., Francou, B., Soruco, A., Gomez, J., Cáceres, B., Ceballos, J.L., Basantes, R. 2013. Current state of glaciers in the Tropical Andes: A multi-century perspective on glacier evolution and climate change. Cryosphere 7 (1), 81-102. https://doi.org/10.5194/tc-7-812013.

Rakesh, B., Bolch, T. 2009. Glacier mapping: A review with special reference to the Indian Himalayas. Progress in Physical Geography 33 (5), 672-704. https://doi. org/10.1177/0309133309348112.

Ruffner, B., Kevin C., 1995. Corona: America's first satellite program. New York, Morgan James. Schauwecker, S., Rohrer, M., Acuña, D., Cochachin, A., Dávila, L., Frey, H., Giráldez, C.. 2014. Climate trends and glacier retreat in the Cordillera Blanca, Peru, revisited. Global and Planetary Change 119, 85-97. https://doi.org/10.1016/j.gloplacha.2014.05.005.

Schauwecker, S., Rohrer, M., Huggel, C., Endries, J., Montoya, N., Neukom, R., Perry, B., Salzmann, N., Schwarb, M., Suarez, W. 2017. The freezing level in the tropical Andes, Peru: An indicator for present and future glacier extents. Journal of Geophysical Research 122 (10), 5172-5189. https://doi.org/10.1002/2016JD025943.

Silverio, W., Jaquet, J.M. 2017. Evaluating glacier fluctuations in Cordillera Blanca (Peru) by remote sensing between 1987 and 2016 in the context of ENSO. Archives Des Sciences 69 (2), 145-162. https://www.scopus.com/inward/record.uri?eid=2-s2.0-85032800993\&partner $\mathrm{ID}=40 \& \mathrm{md} 5=158423 \mathrm{a} 8 \mathrm{f} 7 \mathrm{~b} 3156 \mathrm{~d} 7 \mathrm{c} 6 \mathrm{ee} 00117845 \mathrm{ef} 2$.

Veettil, K, de Souza, S.F. 2017. Study of 40-year glacier retreat in the Northern Region of the Cordillera Vilcanota, Peru, using satellite images: Preliminary results. Remote Sensing Letters 8 (1), 78-85. https://doi.org/10.1080/2150704X.2016.1235811.

Veettil, K, Wang, S., Simões, J.C., Ruiz-Pereira, S.F., de Souza, S.F. 2018. Regional climate forcing and topographic influence on glacier shrinkage: Eastern cordilleras of Peru. International Journal of Climatology 38 (2), 979-995. https://doi.org/10.1002/joc.5226.

Vuille, M., Bradley, R.S., Werner, M., Keimig, F. 2003. 20th century climate change in the tropical Andes: Observations and model results. Climatic Change 59 (1-2), 75-99. https://doi. org/10.1023/A:1024406427519.

Vuille, M., Carey, M., Huggel, C., Buytaert, W., Rabatel, A., Jacobsen, D., Soruco, A. 2018. Rapid decline of snow and ice in the tropical Andes - impacts, uncertainties and challenges ahead. Earth-Science Reviews 176, 195-213. https://doi.org/10.1016/j.earscirev.2017.09.019.

Vuille, M., Franquist, E., Garreaud, R., Sven, W., Casimiro, L., Cáceres, B. 2015. Impact of the global warming hiatus on Andean temperature. Journal of Geophysical Research: Atmospheres 120 (9), 3745-3757. https://doi.org/10.1002/2015JD023126. 
